\title{
The nutrient intakes of pregnant and lactating mothers of good socio-economic status in Cambridge, UK: some implications for recommended daily allowances of minor nutrients
}

\author{
By A. E. BLACK, S. J. WILES ANd A. A. PAUL \\ MRC Dunn Nutrition Unit, Downham's Lane, Milton Road, Cambridge CB4 1 XJ
}

(Received 5 February 1985-Accepted 3 February 1986)

\begin{abstract}
1. Forty-two mothers from social classes I, II and IIInon-manual and twenty-one from social classes IIImanual (M), IV and V were studied longitudinally. The mean daily nutrient intakes in months 4-9 of pregnancy, months 2-4 of lactation and 3 and 6 months post-lactation are presented and are compared with the UK and the US recommended daily allowances (RDA).

2. The quality of the diets (nutrients per $4184 \mathrm{~kJ}$ (1000 kcal)) was found to be better than that of other adult female populations studied in the UK, except for a group of dietitians.

3. The mean daily intakes of nutrients for which there are UK RDA were almost all greater than $100 \%$ of the RDA. The exceptions were iron, which in the manual group (social classes IIIM, IV and V) was $85 \%$ of the RDA in pregnancy and $75 \%$ post-lactation, and vitamin $\mathrm{D}$.

4. Among the nutrients for which there are US, but not UK RDA, only phosphorus and vitamin $B_{12}$ intakes were greater than $100 \%$ of the RDA in both groups at all stages of the study. Intakes of other nutrients were below the RDA: pantothenate $70-91$, vitamin $B_{6}$, zinc, vitamin $E$ and copper $40-72$, folate $21-44$, and biotin $<20 \%$ of the RDA.

5. The bases of the RDA for adult women were examined; for most nutrients the information is limited. It was concluded that the RDA for magnesium, vitamin $\mathrm{E}$ and pantothenate are probably higher than necessary and that deficiency is unlikely; that zinc, copper, vitamin $\mathbf{B}_{6}$ and folate are probably 'marginal' nutrients for 'at risk' groups; and that information on biotin is insufficient even roughly to assess the dietary requirement.
\end{abstract}

Recommended daily allowances (RDA) are normally set at levels believed to cover the needs of the majority of the population. The Department of Health and Social Security (DHSS) (1979) defines them as 'the amount of the nutrient which should be provided per head in a group of people if the needs of practically all members of the group are to be met', and in the USA the National Research Council (1980) Food and Nutrition Board defines them as 'the level of intake ... considered ... adequate to meet the ... needs of practically all healthy persons'.

There are three main bases for establishing RDA: knowledge of the intakes of apparently normal, healthy populations and of populations known to be deficient; knowledge of the amounts required to cure clinical or biochemical signs of deficiency; and studies of metabolism such as measurement of rates of nutrient turnover, or of levels required to maintain metabolic balance or tissue saturation. Such information is used to establish an average requirement for the population, which is then increased by a factor to allow for variability of requirement within that population, and a further factor to allow for inefficient utilization (poor absorption, inefficient conversion of precursors, etc.).

The tendency therefore is to set RDA higher rather than lower, and to set them at levels greater than the needs of many individual members of the population. This tendency may be exaggerated when information on which to base estimates of requirements is scanty, and the committees add large 'margins of safety'.

The wish to err on the safe side is understandable. But, if the RDA are set at too high a level, they can be unrealistic targets in practical terms for the planning of food supplies and diets, and can also lead to misleadingly high estimates of the incidence of malnutrition. Furthermore, if the RDA cannot be covered even by good-quality diets, then one must ask whether all populations are suboptimally nourished, or whether the RDA are overgenerous. 
In the present paper the nutrient intakes of an apparently normal healthy group of women of good socio-economic status in Cambridge, UK, who were studied longitudinally throughout pregnancy and lactation, are examined. The diets of the majority of these women may be regarded as being of optimum quality within the context of current British eating patterns. We compare their nutrient intakes with the current UK and US RDA (DHSS, 1979; (US) National Research Council, 1980) and discuss some of the apparent inadequacies.

\section{EXPERIMENTAL}

The results presented here were obtained as part of a longitudinal study on maternal food intake during pregnancy and lactation, and on the food intake (breast milk and 'solids') of their infants. Anthropometric, clinical and social data were also collected. Only results on maternal food intake are presented here; the energy intake of the infants has been previously reported (Whitehead \& Paul, 1981; Black et al. 1983).

\section{Plan of the study}

Mothers were recruited in June-November 1978 and in June-November 1979. They were followed throughout pregnancy and after the birth of the baby until either they gave up breast-feeding (1978 recruitment) or the baby was 18 months old (1979 recruitment). During pregnancy, mothers were visited each month by a nutritionist to obtain $4 \mathrm{~d}$ weighed records of dietary intake. The records alternated between Wednesday-Saturday and Sunday-Wednesday.

When her baby was 6 weeks old, the mother kept records for four consecutive days of her own diet, of the baby's breast-milk intake and of the baby's intake of any other foods, drinks or medicines. These records were repeated at monthly intervals. As before, records alternated between Wednesday-Saturday and Sunday-Wednesday, and thus were collected at intervals of 4.5 weeks. Records of the mother's diet were also obtained at 3 and 6 months after breast-feeding ended. Although diet records were normally kept for $4 \mathrm{~d}$, there were some exceptions. Four mothers in the final sample kept only one record during pregnancy, for $7 \mathrm{~d}$ in the 9 th month. Also, of fifty-six mothers with records at 3 or 6 months postlactation, thirty-seven had two $4 \mathrm{~d}$ records, but fourteen had one $7 \mathrm{~d}$ record and five had one $4 \mathrm{~d}$ record.

\section{Subjects}

Subjects were recruited from one of the two weekly ante-natal booking clinics at the Maternity Hospital and were 12-16 weeks pregnant. Those living in Cambridge town and in certain designated villages, who were not likely to be moving from the area within the next 12 months, and who had the stated intention of breast-feeding, were eligible for the study. Approximately $50 \%$ of those mothers eligible to join the study did so. Further volunteers were recruited in the 8th month of pregnancy through the ante-natal classes of the National Childbirth Trust (NCT). A small number also joined the study through word-of-mouth from friends. Table 1 shows the numbers recruited and the co-operation achieved.

The present study was concerned with individuals and it was not intended to recruit a representative sample. Nevertheless, it is relevant to consider how the sample relates to the general population. Table 2 shows the distribution by social class according to husband's occupation (Office of Population Census and Surveys, 1970) of national samples of mothers studied by Martin \& Monk (1982), of all Cambridge mothers delivering in the maternity hospital during January-March 1978 (Whichelow \& King, 1979), and of the subjects participating in our study. This shows that Cambridge, a university town with no heavy 
Table 1. Number recruited and co-operation rates

\begin{tabular}{lc}
\hline \hline Numbers enrolled: & 67 \\
From the ante-natal clinic & 12 \\
NCT members and other volunteers & 79 \\
Total & 5 \\
Withdrew during pregnancy & 2 \\
Withdrew shortly after delivery & 8 \\
Records rejected (five poor records, & \\
two premature deliveries at 7 months, & \\
one baby with congenital defect) & 5 \\
To bottle feeding: & 5 \\
at < 1 month & 4 \\
$1-2$ months & 0 \\
$2-3$ months & 2 \\
$3-4$ months & 16 \\
$4-5$ months & $48^{*}$ \\
Total & \\
Breast-fed for > 5 months
\end{tabular}

NCT, National Childbirth Trust.

* No maternal diet records available for one subject in this group.

Table 2. Social class distribution of Cambridge mothers compared with national samples studied by Martin \& Monk (1982)

(1) Comparison with the national sample (\% of subjects in each social class)

\begin{tabular}{|c|c|c|c|c|}
\hline \multirow[b]{3}{*}{ Non-manual } & \multicolumn{2}{|c|}{$\begin{array}{c}\text { National samples } \\
\text { (Martin \& Monk, } \\
\text { 1982) }\end{array}$} & \multicolumn{2}{|c|}{$\begin{array}{l}\text { Cambridge } \\
\text { samples }\end{array}$} \\
\hline & 1975 & 1980 & A & B \\
\hline & $35 \cdot 6$ & $34 \cdot 9$ & $58 \cdot 7$ & $67 \cdot 1$ \\
\hline Manual & $57 \cdot 8$ & $57 \cdot 1$ & $41 \cdot 3$ & $32 \cdot 9$ \\
\hline Not classified & $6 \cdot 6$ & 8.0 & & \\
\hline
\end{tabular}

(2) Comparison of present sample $(B$ and $C)$ with the Cambridge population $(A)$

(Whichelow \&

King, 1979)

Social class $\dagger$

I

II

IIInon-manual

IIImanual

IV and V

Total

\begin{tabular}{rr}
\hline$n$ & \multicolumn{1}{c}{$\%$} \\
68 & $28 \cdot 3$ \\
56 & $23 \cdot 9$ \\
13 & $6 \cdot 5$ \\
73 & $32 \cdot 2$ \\
22 & $9 \cdot 1$ \\
232 & $100 \cdot 0$
\end{tabular}

(Present study)

n $\%$

22

24

7

20

6

79
C

(Present study)

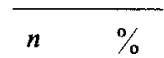

$27 \cdot 8 \quad 14^{*} \quad 29 \cdot 2$

$30.4 \quad 17 \quad 35.4$

$\begin{array}{lll}8.9 & 3 & 6.3\end{array}$

$25 \cdot 3 \quad 12 \quad 25 \cdot 0$

$\begin{array}{lll}7.6 & 2 & 4 \cdot 2\end{array}$

$100 \cdot 0 \quad 48^{*} \quad 100 \cdot 1$

A, all deliveries by Cambridge residents in the maternity hospital during Jan.-Mar. 1978 ( $n$ 232; Whichelow \& King, 1979); B, all subjects participating in the present study ( $n$ 79); C, successful breast-feeders $(n 48)$.

* No maternal diet records for one subject.

$\uparrow$ Classified according to Office of Population Census and Surveys (1970). 
industry, has a social structure biased towards the upper socio-economic groups. The social class distribution of our sample (B) was broadly similar to the 'all Cambridge residents' group (A), but did include a higher proportion of social class II and a lower proportion of IIImanual (M). This is consistent with previous experience (Black, 1973) that social class II is the most willing to co-operate in surveys, and with the fact that the selection procedure eliminated those with no intention of breast-feeding of whom a higher proportion would be in the manual groups (Martin \& Monk, 1982).

\section{Dietary records}

Records of mothers' dietary intake were obtained by $4 \mathrm{~d}$ weighed-diet records (some records were for $7 \mathrm{~d}$; see p. 60). Subjects were visited by a nutritionist twice monthly, once to deliver equipment and once to collect and check through the record. Salter's 512 dietary scales weighing to $900 \mathrm{~g} \times 5 \mathrm{~g}$, two light-weight melamine plates (one large, one small) and a special book for recording were provided. Mothers were instructed in the method of cumulative weighing (Marr, 1961). Food was weighed at the time of service in the form as eaten. Where composite dishes, e.g. stews, quiches, curries, vegetarian dishes or mixed salads were eaten the subject was asked to record the ingredients, an indication of quantities used in the whole recipe and an estimate of the proportion of the whole eaten by herself. Where there was no equivalent recipe in the food tables, the dish was coded as the individual ingredients.

In theory all food and drink were weighed. In practice, some compromises were necessary. Sweets and biscuits, and sometimes other items bought in standard sizes, were recorded as number eaten or price, or both. Cups or mugs of tea or coffee and other drinks taken regularly were recorded as such, and representative items weighed on each record. Teaspoons of sugar and powdered beverages were recorded as such, and ten times a representative spoonful weighed on several occasions.

Inevitably, some meals were taken away from home and were not weighed. This rarely applied to more than one meal in any $4 \mathrm{~d}$ record. On these occasions food items were recorded in numbers, in household measures, or in terms of the dimensions of standard diagrams on the back page of the record book. Where possible, similar items were bought and weighed, or the same meals were eaten in the same restaurants by the survey workers and weighed, or estimated weights were assigned from a file of accumulated information on portion weights.

Nutrient intake was calculated from McCance and Widdowson's The Composition of Foods (Paul \& Southgate, 1978) with additional recipes (Wiles et al. 1980) and information from manufacturers.

The study was approved by the ethical committees of the Dunn Nutrition Unit and the Cambridge Health Authority.

\section{RESULTS}

\section{General characteristics of the mothers}

The general characteristics of the mothers studied are shown in Table 3. The 'manual' mothers were slightly younger than the 'non-manual' mothers at delivery, but there was no significant difference in height, reported pre-pregnant weights, weight gain in pregnancy or birth weights.

\section{Nutrient intakes}

Full reports of the longitudinal changes in energy and nutrient intakes will be published separately. The purpose of this paper is to examine mean intakes in relation to RDA.

The mean daily nutrient intakes in pregnancy, early lactation and post-lactation are shown in Table 4. Intakes for lactation are for mothers feeding for 5 months or longer. 
Table 3. General characteristics of the mothers studied

(Mean values with their standard errors, no. of subjects in parentheses)

\begin{tabular}{|c|c|c|c|c|}
\hline & \multicolumn{2}{|c|}{$\begin{array}{c}\text { Non-manual } \\
(\mathrm{I}, \mathrm{II} \text { and IIINM)† } \\
(n \text { 42) }\end{array}$} & \multicolumn{2}{|c|}{$\begin{array}{c}\text { Manual } \\
(\text { IIIM, IV and V) } \\
(n \text { 21) }\end{array}$} \\
\hline & Mean & SE & Mean & SE \\
\hline Age at delivery (years) & $29 \cdot 1$ & 0.54 & $27 \cdot 0^{*}$ & 0.83 \\
\hline Height $(\mathrm{m})$ & 1.63 & 0.0087 & 1.61 & 0.0124 \\
\hline Reported pre-pregnant wt (kg) & $56 \cdot 6$ & $1 \cdot 02$ & $56 \cdot 2$ & $1 \cdot 23$ \\
\hline Wt gain in pregnancy $(\mathrm{kg})$ & $12 \cdot 7$ & 0.66 & $11 \cdot 9$ & $0 \cdot 88$ \\
\hline \multicolumn{5}{|l|}{ Birth wt (kg) } \\
\hline Boys & $3 \cdot 46$ & $0.08(28)$ & $3 \cdot 49$ & $0 \cdot 20(9)$ \\
\hline Girls & $3 \cdot 27$ & $0 \cdot 12(14)$ & $3 \cdot 27$ & $0.07(12)$ \\
\hline
\end{tabular}

* Significantly different from non-manual group $(P<0 \cdot 05)$.

$\dagger$ Classified according to Office of Population Census and Surveys (1970).

Those subjects designated as 'unsuccessful' breast-feeders included eight mothers giving up apparently due to low motivation at $0-3$ months, and eight mothers with apparently unsatisfied babies who all seemed more contented when changed to bottle feeding between 1 and 4 months.

Intakes in pregnancy were calculated as the mean intake over all days measured in months 4-9, an average of $20 \mathrm{~d}$ per subject. Lactation intakes were calculated as the mean intake over months 2, 3 and 4 of lactation ( $12 \mathrm{~d}$ per subject). Post-lactation intakes were the mean of days recorded at 3 and 6 months post-lactation ( $8 \mathrm{~d}$ per subject). There was no difference in the energy intakes recorded at 3 months and at 6 months post-lactation, and both periods included an unquantifiable element of conscious food restriction. Energy intakes were compared by paired $t$ test. During pregnancy the 'non-manual' group had a significantly higher energy intake than the 'manual' group $(P<0.01)$. Both groups increased their energy intake during the period of maximum lactation, and the 'manual' group did so to a greater extent, such that there was no longer a statistically significant difference between them. In the post-lactation period there was again a significant difference between them $(P<0.001)$.

Energy intakes in lactation of the forty-one subjects with fully longitudinal data ('successful' breast-feeders) were greater than those during pregnancy ('non-manual', $P<0.001$; 'manual', $P<0.01$ ). Post-lactation intakes in these subjects were lower than the pregnancy intakes; this difference was significant in the 'non-manual' group $(P<0.05)$ but not in the 'manual' group. These differences are probably real and biologically significant, as well as statistically significant.

Intakes of nutrients in general followed the pattern of energy intake, being highest in lactation and lowest in the post-lactation period, with intakes by the 'non-manual' group usually higher than those of the 'manual' group.

\section{Nutrient intakes compared with the RDA}

In Table 4 the nutrient intakes are also expressed as percentages of the RDA.

Nutrients fall into two categories: group A, those for which RDA are well established and given in both the UK and the US tables, and group B, those for which either an RDA, or a value for 'estimated safe and adequate daily intake' (ESADI) appears in the (US) National Research Council (1980) tables but not in the UK tables. For group A, the majority of mean nutrient intakes were well above the UK RDA. In the 'manual' group, however, 
A. E. Black, S. J. Wiles and A. A. Paul

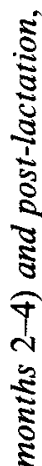

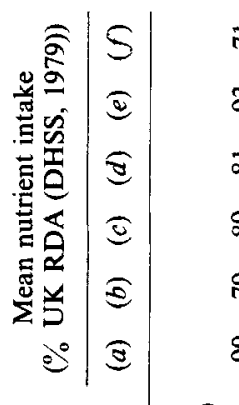

$\overline{1}$

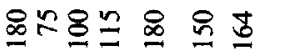

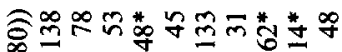

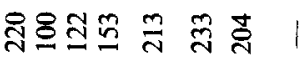

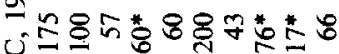

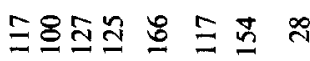

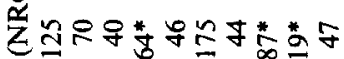

$\infty$

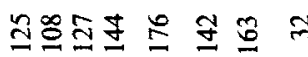

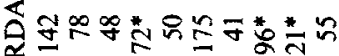

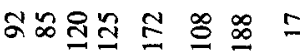

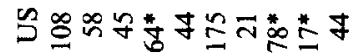

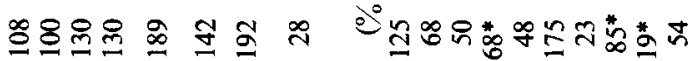

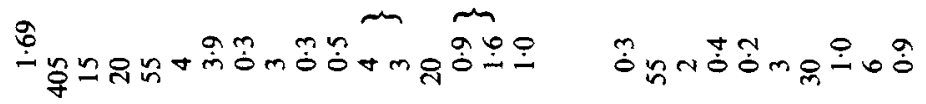

$\Sigma 2$

की

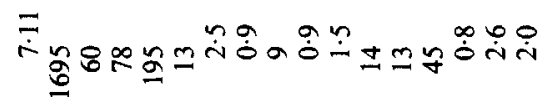

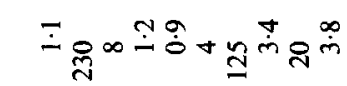

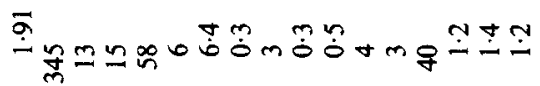

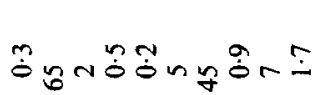

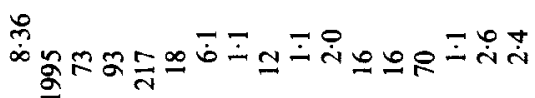

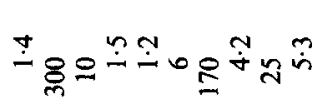

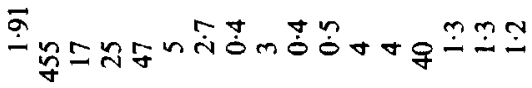

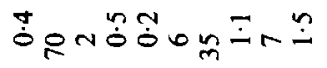

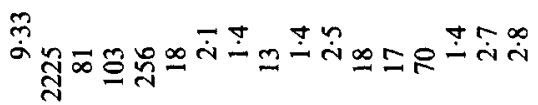

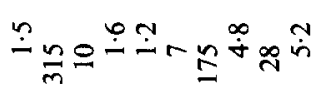

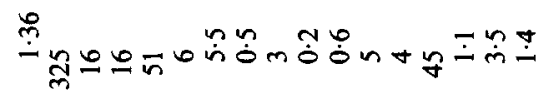

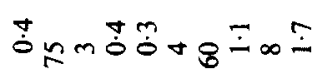

$\sum_{m} m$

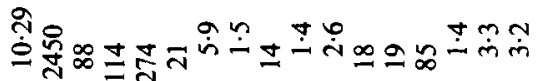

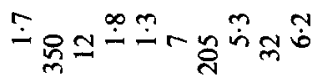

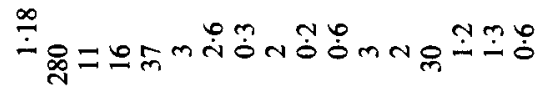

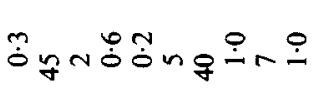

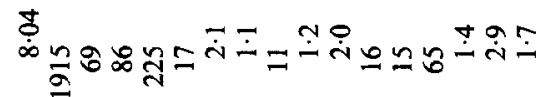

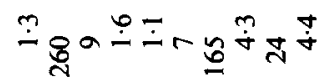

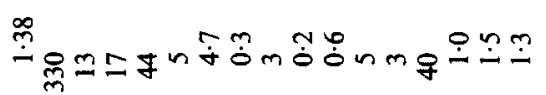

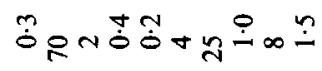

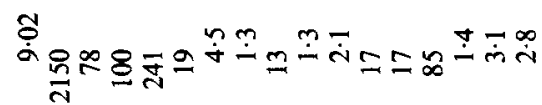

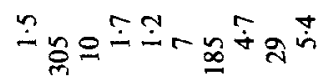

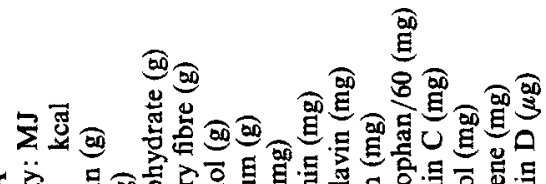

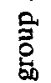

要

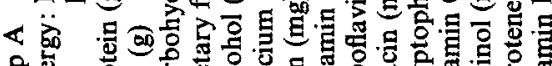

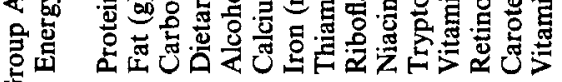

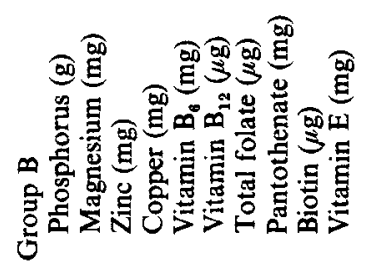


iron intakes were $85 \%$ of RDA in pregnancy and $75 \%$ post-lactation, and calcium intakes in pregnancy were $92 \%$ of RDA; vitamin D was, as in all British diets, well below the RDA.

Of group $\mathbf{B}$ nutrients, only the intakes of phosphorus and vitamin $\mathbf{B}_{12}$ were consistently above $100 \%$; magnesium was above $100 \%$ in one group but between 54 and $90 \%$ in the other five; all other nutrient intakes (\% RDA) were considerably lower than the tentative RDA (or mid-point ESADI): biotin under 20; folate 21-44; vitamin $\mathbf{B}_{6}$, zinc, vitamin $\mathrm{E}$ and copper 40-72; pantothenate 73-91.

\section{DISCUSSION}

\section{Comparison with other studies: energy intakes}

In Table 5 the absolute energy intakes of Cambridge mothers are compared with those found in six other recent studies of adult females, both pregnant and non-pregnant. There was no clear difference in energy intake between pregnant and non-pregnant women. The Cambridge findings suggest a higher intake in mid-late pregnancy than in the non-pregnant (post-lactation) state, but the latter findings included an unquantifiable element of conscious dieting. First-trimester intake recorded by Smithells et al. (1977) was lower than secondand third-trimester intakes recorded by Darke et al. (1980) and in Cambridge (present study), but the findings of Smithells et al. (1977) contained an unquantifiable element of altered appetite due to morning sickness. Neither of the longitudinal studies (Doyle et al. 1982; Cambridge, in the present study) measured intake in the pre-pregnant state.

The question of whether pregnancy intake is the same as the pre-pregnant level in the first trimester, rising in later pregnancy, or whether it drops in the first trimester and returns to pre-pregnant levels in mid-pregnancy is not resolved by looking at the intakes of the non-pregnant groups; their mean intakes range from above to below intakes recorded in pregnant groups.

The lower energy intakes of the 'manual' group compared with the 'non-manual' group agree with findings of other surveys of adult pregnant women (Thomson, 1958; Smithells et al. 1977; DHSS, unpublished results).

\section{Comparison with other studies: diet quality}

In Table 5 the quality of the Cambridge diets expressed as nutrients per $4184 \mathrm{~kJ}$ (1000 kcal) is also compared with that of other adult female populations studied in the UK since 1965. A factor that is usually ignored in comparing results of different surveys is the use of different food tables. At the Dunn Nutrition Unit the data from the 1-year-long study of forty-two dietitians with 20-70 d of values per subject (Black et al. 1984) have been analysed according to both the widely used DHSS food tables (DHSS, unpublished results) and the fourth edition of McCance and Widdowson's The Composition of Foods (Paul \& Southgate, 1978; MW4). MW4 tables gave significantly higher intakes of vitamin $\mathrm{A}(23 \%)$, vitamin $\mathrm{D}(21 \%)$ and riboflavin $(14 \%)$, and significantly lower intakes of vitamin $\mathrm{B}_{6}(14 \%)$ and $\mathrm{Fe}(11 \%)$. Other nutrients differed by 2-6\% (Black et al. 1985a). Therefore in Table 5 the published intakes of all nutrients in surveys which used the DHSS food tables have been multiplied by a 'food table conversion factor, (FTCF):

$$
\text { FTCF }=\frac{\text { Intake calculated by MW4 food tables }}{\text { Intake calculated by DHSS food tables }} \text {. }
$$

It is recognised that these factors have been derived from only one population group. However, there were clear systematic differences between the food tables, and data from other native British groups would certainly show differences in the same direction and probably of similar magnitude (Black et al. 1985a). 
Table 5 shows that the nutrient density of the Cambridge diets in pregnancy and post-lactation was similar. The Cambridge mothers in pregnancy, however, had a nutrient density for vitamins and minerals higher than any of the groups which might be described as 'representative British' (Smithells et al. 1977; Darke et al. 1980; Bingham et al. 1981; Nelson et al. 1985 and unpublished results). Only the dietitians had higher nutrient densities (Black et al. 1984). Curiously, the low socio-economic group of Doyle et al. (1982) also had high nutrient densities; this group, however, was of mixed ethnic origin and the pattern of nutrient densities was also different from the other, all-British groups: protein was relatively high, fat relatively low, and vitamins $B_{6}$ and $D$ were exceptionally high. These differences presumably reflect non-British patterns of food consumption.

Clearly, the nutrient intakes of the Cambridge group represent good-quality diets, and it would be unrealistic to expect an average nutrient intake higher than this from any group eating according to British food patterns and at this level of energy intake. Since one basis for establishing RDA is 'the nutrient intake ... of apparently normal healthy people' ((US) National Research Council, 1980; generally interpreted as the average intake of western populations) the large gap for many group B nutrients (Table 4) between Cambridge intakes and the tentative RDA or ESADI raises several questions. Are suboptimal levels of nutrition widespread? Do food tables underestimate intake? Are the RDA unnecessarily high?

The first question cannot be answered for this group, since no biochemical measurement was made that relates to the nutrients under discussion. We can only judge the possibility of some members of the group having inadequate intakes against the information about requirements that was used as the basis for the RDA, as discussed later.

\section{Do the food tables underestimate intakes?}

While there are many difficulties in compiling food tables, and many limitations on the validity of the data (analytical problems, normal variation in composition of foods, limitations of the number of samples that can be analysed), it is generally believed that calculated nutrient intakes are of the right order of magnitude. The only nutrient for which the food table values have been seriously questioned is folate. Bates et al. (1982) concluded that food folate values might be considerably underestimated. Assay techniques for vitamin $B_{6}$, however, are also known to be less than satisfactory (Cooke, 1983). Since it occurs in several forms the assay procedure is complicated, requiring acid hydrolysis to release bound forms and separate assay of the three free forms (Polansky, 1981), and there is insufficient knowledge about the availability of the various forms (Haskell, 1978).

For pantothenic acid and biotin, the calculated intakes are based on more limited information than that for other nutrients. For many foods, notably biscuits and breakfast cereals, there is no value in the food tables; we estimate that our Cambridge subjects might obtain a further $5 \mu \mathrm{g}$ biotin and $0.6 \mathrm{mg}$ pantothenate from such foods, giving total overall mean daily intakes of $35 \mu \mathrm{g}$ and $5.2 \mathrm{mg}$ respectively (Black et al. 1985 $\mathrm{b}$ ). This brings pantothenate intake inside the range of 4-7 mg suggested as an ESADI, but leaves biotin intake still well below the ESADI of $100-200 \mu \mathrm{g}$.

\section{Are the RDA too high?}

The significance of the apparently low energy intakes has been discussed by Whitehead \& Paul (1982).

In spite of low energy intakes, the group A nutrients with the exception of Fe were well covered. It is established that $\mathrm{Fe}$ intakes may not be adequate for women with the highest requirements as evidenced by the wide range of menstrual losses (Hallberg et al. 1966) and the presence of anaemia in unsupplemented populations (Elwood et al. 1967; Jacobs et al. 1969). The discussion therefore concentrates on those nutrients in group B where 


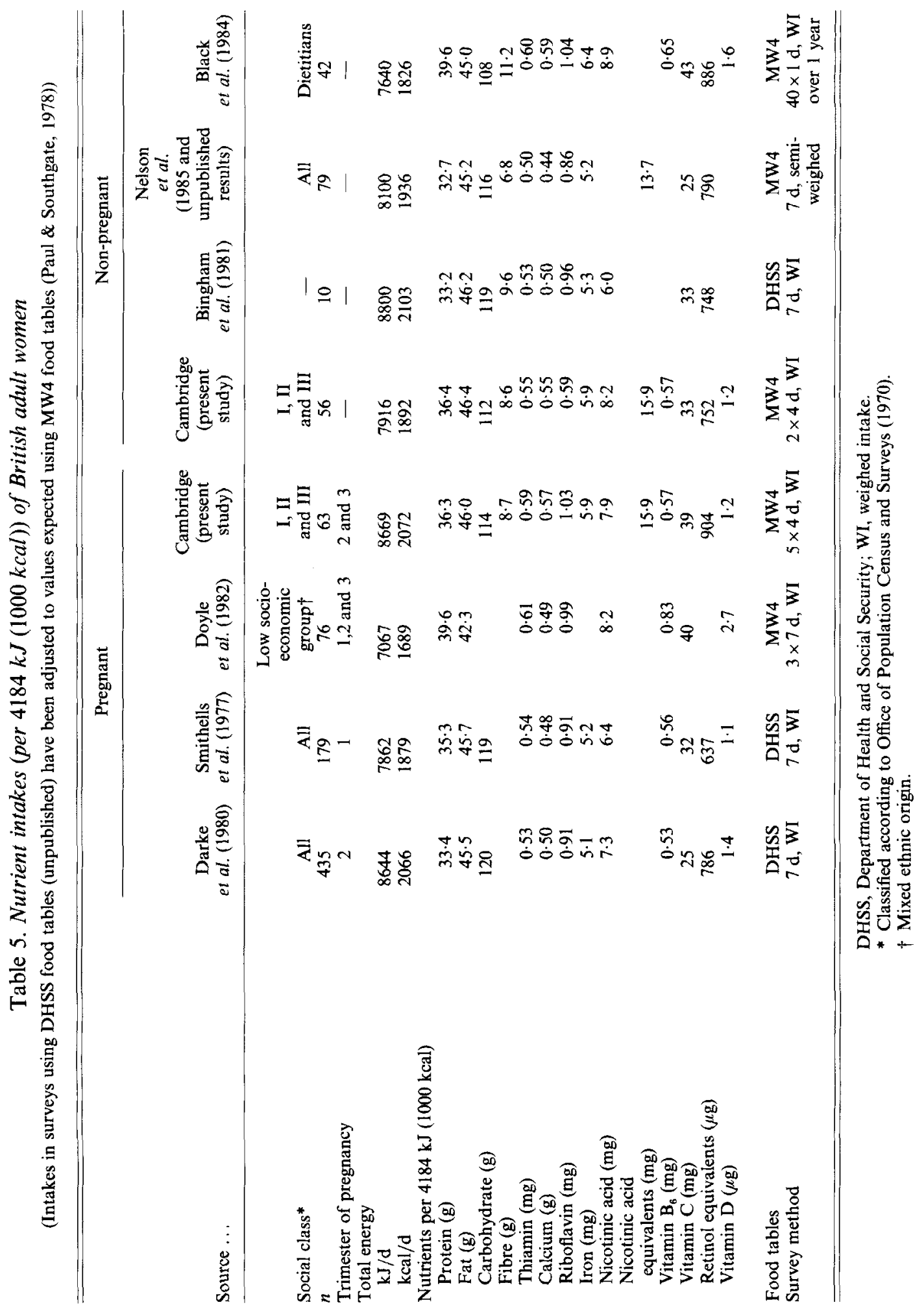


the intake was apparently inadequate, and examines briefly the bases of the adult female RDA. No attempt is made at a critical examination of the increments recommended for pregnancy or for lactation.

$M g(R D A 300 \mathrm{mg}$ ). Cambridge mean intakes ranged from 230 to $350 \mathrm{mg} / \mathrm{d}$. A similar value $(320 \mathrm{mg} / \mathrm{d})$ has been reported as the national average intake in Switzerland (Hunziker \& Zimmerli, 1982). The RDA leans heavily on a review of balance studies by Seelig (1964), which concludes that the minimum $\mathrm{Mg}$ requirement is $6 \mathrm{mg} / \mathrm{kg}$ body-weight per $\mathrm{d}$ or $330 \mathrm{mg} / \mathrm{d}$ for a $55 \mathrm{~kg}$ woman. Marshall et al. (1976), however, consider that both this estimate and the RDA are too high. They find that negative $\mathrm{Mg}$ balance can be prevented with intakes as low as $100 \mathrm{mg} / \mathrm{d}$. A recent study on adult males showed positive balance with intakes of $229 \mathrm{mg}$ (Mahalko et al. 1983). Since intakes as low as 10-20 mg are required to produce deppletion (Fourman, 1961; Shils, 1969), and deficiency states are unknown except in pathological conditions, the RDA does appear to be too high.

$Z n(R D A 15 \mathrm{mg})$. Cambridge mean intakes ranged from 8 to $12 \mathrm{mg} / \mathrm{d}$. Similar mean intakes, 7-12 mg/d have been reported in many other studies (Greger \& Sciscoe, 1977; Abdulla et al. 1977; Hunt et al. 1979; Spring et al. 1979; Freeland-Graves et al. 1980; Harland et al. 1980; Krebs et al. 1980; Flint et al. 1981; Bunker et al. 1982; Sandström, 1982). Moser \& Allen (1984) and Black (1986) have shown that an intake of $15 \mathrm{mg}$ (the RDA for women neither pregnant nor lactating) cannot be achieved except by individuals with exceptionally high energy intakes.

Factorial calculations (World Health Organization, 1973) and work with patients on parenteral nutrition (Wolman et al. 1981) indicate that adults require to absorb 2-4 mg $\mathrm{Zn} / \mathrm{d}$. Whether this can be achieved depends on the availability of $\mathrm{Zn}$ in the diet. The World Health Organization (1973) suggested that this ranged from 10 to $40 \%$, and Solomons (1982) in a comprehensive review concurred. A value of $35 \%$ has been used for western diets (Dreosti, 1982). Radioisotope studies suggest a turnover of $6 \mathrm{mg} / \mathrm{d}$ (Richmond et al. 1962; Engel et al. 1966) and balance studies have shown equilibrium or positive balance on intakes of $12.5 \mathrm{mg} / \mathrm{d}$ from a mixed diet (Spencer et al. 1976). These values are equivalent to $2-4 \mathrm{mg}$ $\mathrm{Zn}$ at $35 \%$ absorption. There may be a considerable degree of adaptation to habitual dietary intakes. There is evidence from depletion-repletion studies of rapid adjustments in $\mathrm{Zn}$ absorption and excretion during acute depletion, and of dose-dependent absorption of $\mathrm{Zn}$ supplements (Istfan et al. 1983; Milne et al. 1983; Taylor Baer \& King, 1984). Nevertheless, experience with patients on parenteral nutrition and depletion-repletion experiments have shown that $\mathrm{Zn}$ depletion can occur quite readily. Several studies have suggested the presence of $\mathrm{Zn}$ deficiency in the population (Henkin et al. 1971; Hambidge et al. 1972, 1976; Pories et al. 1976). In a longitudinal study of pregnant women on unsupplemented diets of $11 \mathrm{mg}$ and supplemented diets of $22 \mathrm{mg} \mathrm{Zn} / \mathrm{d}$, Hambidge et al. (1983) concluded, on the basis of the higher alkaline phosphatase (EC 3.1.3.1) activities, that the unsupplemented intake of $11 \mathrm{mg}$ was suboptimal. $\mathrm{Zn}$ intakes are probably marginal even in western diets. That is, a significant number of individuals with intakes at the lower end of the range are likely to be deficient.

$C$. (ESADI 2-3 mg). Cambridge mean intakes ranged from 1.2 to $1.8 \mathrm{mg} / \mathrm{d}$; other studies have found intakes as low as or lower than these (White, 1969; Abdulla et al. 1977; Guthrie \& Robinson, 1977; Holden et al. 1979; Spring et al. 1979; Klevay et al. 1979) and it is clear that individual intakes of $<1 \mathrm{mg} / \mathrm{d}$ are not rare. In a recent review Sandstead (1982) concluded that the ESADI of 2-3 mg was appropriate and that marginal $\mathrm{Cu}$ deficiency might not be uncommon.

Vitamin $B_{6}(R D A 2.0 \mathrm{mg})$. Cambridge mean intakes ranged from 0.9 to $1.3 \mathrm{mg} / \mathrm{d}$. Mean dietary intakes do not normally approach the value of $2 \mathrm{mg}$ quoted as the adult female RDA; mean intakes ranging from 0.88 to $1.60 \mathrm{mg} / \mathrm{d}$ have been reported (see Driskell \& 
Chrisley, 1981). Guthrie \& Crocetti (1983) also pointed out that it is difficult to plan menus that meet the RDA using commonly acceptable combinations of foods at the energy intakes reported for US populations. The RDA is based primarily on results of depletion-repletion experiments. Interpretation is difficult owing to the varying design of the studies. It is clear, however, that diets containing $<0.5 \mathrm{mg} / \mathrm{d}$ are deficient and those containing $>2.0 \mathrm{mg} / \mathrm{d}$ reverse the signs of deficiency. In between is a grey area.

Vitamin $B_{6}$ requirement is related to protein intake, and the second basis for establishing the RDA is $0.02 \mathrm{mg}$ vitamin $\mathrm{B}_{6} / \mathrm{g}$ protein intake. On the basis that many adult-female diets do contain up to $100 \mathrm{~g}$ protein/d, the US RDA was set at $2.0 \mathrm{mg}$. Guthrie \& Crocetti (1983), however, have pointed out that the average protein intake for adult women is about $70 \mathrm{~g} / \mathrm{d}$ and that many take less than $100 \mathrm{~g}$. The Canadian RDA (Department for National Health and Welfare, 1982) are based on $0.02 \mathrm{mg} / \mathrm{g}$ average protein intake, and stand at $1.5 \mathrm{mg}$ for women, with an additional $0.5 \mathrm{mg}$ for pregnancy and $0.6 \mathrm{mg}$ for lactation. Using these values the mean intakes of Cambridge mothers ranged from 52 to $78 \%$ of requirement.

Some studies have shown a significant proportion of individuals to have biochemical indices of vitamin $\mathrm{B}_{6}$ status at levels considered indicative of deficiency (e.g. Driskell et al. 1976; Hampton et al. 1977; Kirksey et al. 1978), but more work needs to be done to assess the vitamin $B_{6}$ status of normal populations on known intakes of vitamin $\mathbf{B}_{6}$ and to determine the biological availability in the diet.

Pantothenic acid (ESADI 4-7 mg). Cambridge mean intakes ranged from $3 \cdot 4$ to $5 \cdot 3 \mathrm{mg} / \mathrm{d}$, with a possible additional $0.6 \mathrm{mg}$ not accounted for by food tables. Mean daily intakes of 5.6 and $5.4 \mathrm{mg}$ have been reported by Kathman \& Kies (1984). Deficiency has only been obtained by the use of semi-synthetic diets (Fry et al. 1976) or antagonists (Hodges et al. 1959). The ESADI of $4-7 \mathrm{mg}$ was based on the range of reported dietary intakes. In view of the difficulty of producing deficiency it seems likely that the lower value is sufficient to maintain clinical health.

Biotin (ESADI 100-200 $\mu$ ). This nutrient shows the greatest discrepancy between reported intakes and ESADI. Cambridge intakes ranged from 20 to $32 \mu \mathrm{g} / \mathrm{d}$, with a possible additional $5 \mu \mathrm{g}$ not accounted for by food tables. The ESADI seems primarily based on the statement that 'mixed American diets are thought to provide an intake of $100-200 \mu \mathrm{g} / \mathrm{d}$ for adults'. This statement is unreferenced and in conflict with other estimates of dietary intake of 50-100 and $70 \mu \mathrm{g}$ (Bonjour, 1977), and $60 \mu \mathrm{g}$ (Hoppner et al. 1978). More recently, UK intakes have been estimated at $35.5 \mu \mathrm{g} / \mathrm{d}$ nationally (Bull \& Buss, 1982). However, Paul \& Southgate (1978) in their introduction to McCance and Widdowson's The Composition of Foods say 'Recent improvements in [analytical] techniques have resulted in lower amounts in foods... [which] are believed to be more correct than the older ones'. Given this confusion, the virtual absence of biochemical evidence on which to base an RDA, the fact that gut flora may contribute to intake, and the absence of deficiency syndromes except in peculiar circumstances, it seems misleading to define even an ESADI.

Vitamin $E$ (RDA $8 \mathrm{mg}$ ). Cambridge intakes ranged from 3.8 to $6.2 \mathrm{mg} / \mathrm{d}$. The RDA of $8 \mathrm{mg}$ for an adult female is based on the assumption that US diets are adequate, and the statement that they contain 7-13 mg D- $\alpha$-tocopherol equivalents in balanced diets supplying $7 \cdot 5-12.5 \mathrm{MJ}(1800-3000 \mathrm{kcal}) / \mathrm{d}$. RDA are given in terms of $\alpha$-tocopherol equivalents, but the total activity in mixed diets is uncertain due to lack of measurement of tocopherols other than $\alpha$-tocopherol. (US) National Research Council (1980) recommended multiplying $\alpha$-tocopherol intakes by 1.2 to give total vitamin $\mathrm{E}$ activity. Cambridge intakes increased by a factor of $1 \cdot 2$ would be $4 \cdot 2-7 \cdot 4 \mathrm{mg} / \mathrm{head}$ per $\mathrm{d}$ (or $2 \cdot 5-3 \cdot 1 \mathrm{mg} / 4184 \mathrm{~kJ}$ (1000 kcal)). These are probably still underestimates since no account was taken of vitamin $\mathrm{E}$ in cooking oil. Other published studies give intakes of $\alpha$-tocopherol of $2.3-3.0 \mathrm{mg} / 4184 \mathrm{~kJ}(1000 \mathrm{kcal})$ (Thompson et al. 1973; Witting \& Lee, 1975; Bull \& Buss, 1982). A maximum mean intake 
of vitamin $\mathrm{E}$ (in diets $12.5 \mathrm{MJ}(3000 \mathrm{kcal})$ is unlikely to exceed $11 \mathrm{mg}$ vitamin $\mathrm{E}$ intake. Mean intakes of most groups are probably in the range $4-8 \mathrm{mg} / \mathrm{d}$.

Since vitamin E deficiency is unknown except in premature infants, the RDA is probably higher than necessary. Vitamin $\mathrm{E}$ requirement is related to the polyunsaturated fatty acid (PUFA) intake, being greater when PUFA intake is higher. This, however, does not cause problems, since good sources of PUFA are also good sources of $\alpha$-tocopherol.

Folate $(R D A 400 \mu \mathrm{g})$. Bates et al. (1982) have concluded that "current values for food folates may be quite seriously underestimated', and the margins of safety applied to the committees which generated the RDA 'seem perhaps somewhat excessive'. However, studies (summarized by Chanarin, 1981) indicating the presence of megaloblastic anaemia in pregnant women, work by Smithells et al. (1981) indicating a possible role in the occurrence of neural tube defects, and the probable existence of marginal deficiency in the elderly (Chanarin, 1981), show that folate intake may be inadequate for some sections of the population.

\section{Conclusion}

We conclude that the RDA (ESADI) for magnesium, vitamin E, pantothenate and biotin are inappropriately high, and dietary deficiency is unlikely.

Although the RDA (ESADI) for $\mathrm{Zn}, \mathrm{Cu}$, vitamin $\mathrm{B}_{6}$ and folate probably include over-generous safety factors, the information on requirements which form the bases for the RDA also suggests that intakes of these nutrients may be marginal. Suboptimal intakes are likely among women taking diets in the lower range of energy intakes and of low nutrient density.

The authors would like to thank Mr Ken Day for computing, students from the University of Surrey for help with field work, the Cambridge Maternity Hospital and, above all, the mothers themselves for their cheerful collaboration and patience with our demands.

\section{REFERENCES}

Abdulla, M. F., Jagerstad, M., Norden, A., Qvist, I. \& Svensson, S. (1977). Nutrition and Metabolism 21, Suppl. $1,41-44$.

Bates, C. J., Black, A. E., Phillips, D. R., Wright, A. J. A. \& Southgate, D. A. T. (1982). Human Nutrition: Applied Nutrition 36 A, 422-429.

Bingham, S. A., McNeil, N. I. \& Cummings, J. H. (1981). British Journal of Nutrition 45, 23-35.

Black, A. E. (1973). Nutrition, London 27, 245-252.

Black, A. E. (1986). Proceedings of the Nutrition Society 45 (In the press).

Black, A. E., Cole, T. J., Wiles, S. J. \& White, F. (1983). Human Nutrition: Applied Nutrition 37 A, $448-458$.

Black, A. E., Paul, A. A. \& Hall, C. (1985b). Human Nutrition: Applied Nutrition 39 A, 19-22.

Black, A. E., Ravenscroft, C. \& Paul, A. A. (1985a). Human Nutrition: Applied Nutrition 39 A, 9-18.

Black, A. E., Ravenscroft, C. \& Sims, A. J. (1984). Human Nutrition: Applied Nutrition 38 A, 165-179.

Bonjour, J. P. (1977). International Journal for Vitamin and Nutrition Research 47, 107-118.

Bull, N. L. \& Buss, D. H. (1982). Human Nutrition: Applied Nutrition 36 A, 190-196.

Bunker, V. W., Lawson, M. S., Delves, H. T. \& Clayton, B. E. (1982). Human Nutrition: Clinical Nutrition 36 C, 213-221.

Chanarin, I. (1981). In Nutrition Problems in Modern Society, pp. 11-18 [A. N. Howard, editor]. London: John Libbey.

Cooke, J. R. (1983). Human Nutrition: Applied Nutrition 37 A, 441-447.

Darke, S. J., Disselduff, M. M. \& Try, G. P. (1980). British Journal of Nutrition 44, $243-252$.

Department of Health and Social Security (1979). Recommended Daily Amounts of Food Energy and Nutrients for Groups of People in the United Kingdom. Reports on Health and Social Subjects no. 15. London: H.M. Stationery Office.

Department for National Health and Welfare (1982). Recommended Nutrient Intakes for Canadians. Ottawa: Department for National Health and Welfare.

Dreosti, I. E. (1982). Journal of Food and Nutrition 39, 167-173.

Doyle, W., Crawford, M. A., Laurence, B. M. \& Drury, P. (1982). Human Nutrition: Applied Nutrition 36 A, 95-106. 
Driskell, J. A. \& Chrisley, B. M. (1981). In Methods in Vitamin $B_{6}$ Nutrition, pp. 241-252 [J. E. Leklem and R. D. Reynolds, editors.]. New York: Plenum Press.

Driskell, J. A., Geders, J. M. \& Urban, M. C. (1976). Journal of Laboratory and Clinical Medicine 87, 813-821.

Elwood, P. C., Waters, W. E., Greene, W. J. \& Wood, M. M. (1967). British Medical Journal iv, 714-717.

Engel, R. W., Miller, R. F. \& Price, N. O. (1966). In Zinc Metabolism, pp. 326-338. [A. S. Prasad, editor]. Springfield, Illinois: C. C. Thomas.

Flint, D. M., Wahlqvist, M. L., Smith, T. J. \& Parish, A. E. (1981). Journal of Human Nutrition 35, 287-295.

Fourman, P. (1961). Scientific Basis of Medicine Annual Review, 270-282.

Freeland-Graves, J. H., Bodzy, P. W. \& Eppwright, M. A. (1980). Journal of the American Medical Association 77, 655-661.

Fry, P. C., Fox, H. M. \& Tas, H. G. (1976). Journal of Nutritional Science and Vitaminology 22, 339-346.

Greger, J. L. \& Sciscoe, B. C. (1977). Journal of the American Dietetic Association 70, 31-37.

Guthrie, B. \& Robinson, M. F. (1977). British Journal of Nutrition 38, 55-63.

Guthrie, H. \& Crocetti, A. F. (1983). Nutrition Reports International 28, 133-138.

Hallberg, L., Högdahl, A.-M., Nilsson, L. \& Rybo, G. (1966). Acta Obstetrica et Gynecologica Scandinavica 45 , $320-351$.

Hambidge, K. M., Hambidge, C., Jacobs, M. \& Baum, J. D. (1972). Pediatric Research 6, 868-874.

Hambidge, K. M., Krebs, N. F., Jacobs, M. A., Favier, A., Guyette, L. \& Ihle, D. N. (1983), American Journal of Clinical Nutrition 37, 429-432.

Hambidge, K. M., Walravens, P. A., Brown, R. M., Webster, J., White, S., Autbouy, M. \& Roth, M. L. (1976). American Journal of Clinical Nutrition 29, 734-738.

Hampton, D. J., Chrisley, B. M. \& Driskell, J. A. (1977). Nutrition Reports International 16, 743-750.

Harland, B. F., Johnson, R. D., Blenderman, E. M., Prosby, L., Vanderveen, J. E., Reed, G. L., Forbes, A. L. \& Roberts, H. R. (1980). Journal of the American Dietetic Association 77, 16-20.

Haskell, B. F. (1978). In Human Vitamin $B_{8}$ Requirements. Washington, DC: National Academy of Sciences.

Henkin, R. I., Schechler, P. J., Hoye, R. \& Mathern, C. F. T. (1971). Journal of the American Medical Association 27, 1434-1440.

Hodges, R. E., Bean, W. B., Ohlson, M. A. \& Bleiler, B. (1959). Journal of Clinical Investigation 38, $1421-1425$.

Holden, J. M., Wolf, W. R. \& Mertz, W. (1979). Journal of the American Dietetic Association 75, $23-28$.

Hoppner, K., Lamp, B. \& Smith, D. C. (1978). Canadian Institute of Food Science and Technology Journal 11, 71.

Hunt, I. F., Murphy, N. I., Gomez, J. \& Smith, J. C. Jr (1979). American Journal of Clinical Nutrition 32, 1511-1518.

Hunziker, H. R. \& Zimmerli, B. (1982). Mitteilungen aus dem Gebiete der Lebensmitteltmtersuchung und Hygiene 73, 379-393.

Istfan, N. W., Janghorbani, M. \& Young, V. R. (1983). American Journal of Clinical Nutrition 38, 187-194.

Jacobs, A., Waters, S. E., Campbell, H. \& Barrow, A. (1969). British Journal of Haematology 17, 581-587.

Kathman, J. V. \& Kies, C. (1984). Nutrition Research 4, 245-250.

Kirksey, A., Keaton, K., Abernathy, R. P. \& Greger, J. L. (1978). American Journal of Clinical Nutrition 31, 946-954.

Klevay, L. M., Peck, S. J. \& Barcome, D. F. (1979). Journal of the American Medical Association 241, 1916-1918.

Krebs, N. F., Hambidge, K. M., Lyle, C. C., Freeland, S. F., Chanmugan, P. \& Casey, C. E. (1980). Western Hemisphere Nutrition Congress VI, Los Angeles Program 1980, 82, Abstr.

Mahalko, J. R., Sandstead, H. H., Johnson, L. K. \& Milne, D. B. (1983). American Journal of Clinical Nutrition 37, 8-14.

Marr, J. W. (1961). Proceedings of the Nutrition Society 20, xxxix.

Marshall, D. H., Nordin, B. E. C. \& Speed, R. (1976). Praceedings of the Nutrition Society 35, 163-173.

Martin, J. \& Monk, J. (1982). Infant Feeding 1980. London: Office of Population Census and Surveys, Social Survey Division.

Milne, D. B., Canfield, W. K., Mahalko, J. R. \& Sandstead, H. H. (1983). American Journal of Clinical Nutrition 38, $18 \mathrm{l}-186$.

Moser, P. B. \& Allen, D. (1984). Journal of the American Dietetic Association 84, 42-46.

National Research Council (1980). Recommended Dietary Allowances, 9th revised ed. Washington DC: National Academy of Sciences.

Nelson, M., Dyson, P. A. \& Paul, A. A. (1985). British Journal of Nutrition 54, 373-387.

Office of Population Census and Surveys (1970). Classification of Occupations 1970. London: H.M. Stationery Office.

Paul, A. A. \& Southgate, D. A. T. (1978). McCance and Widdowson's The Composition of Foods. 4th ed. London: H.M. Stationery Office.

Polanksy, M. (1981). In Methods in Vitamin $B_{6}$ Nutrition, pp. 21-44. [J. E. Leklem and R. D. Reynolds, editors] New York: Plenum Press.

Pories, W. J., Mansouri, E. G., Plecha, F. R., Flynn, A. \& Strain, W. H. (1976). In Trace Elements in Human Health and Disease, vol. 1, pp. 115-141 [A. S. Prasad, editor.] New York: Academic Press.

Richmond, C. R., Furchner, J. E., Trafton, G. A. \& Langham, W. H. (1962). Health Physics 8, $481-489$.

Sandstead, H. H. (1982). American Journal of Clinical Nutrition 35, 809-814. 
Sandström, B. (1982). Näringsforskning 26, 163-164.

Seelig, M. S. (1964). American Journal of Clinical Nutrition 14, 342-390.

Shils, M. E. (1969). Medicine, Baltimore 48, 61-85.

Smithells, R. W., Ankers, C., Carver, M. E., Lennon, D., Schorah, C. J. \& Sheppard, S. (1977). British Journal of Nutrition 38, 497-506.

Smithells, R. W., Sheppard, S., Schorah, C. J., Seller, M. J., Nevin, M. C., Harris, R., Read, A. P. \& Fielding, D. W. (1981). Archives of Diseases in Childhood 56, 911-918.

Solomons, N. W. (1982). American Journal of Clinical Nutrition 35, 1048-1075.

Spencer, H., Osis, P., Kramer, L. \& Norris, C. (1976). In Trace Elements in Human Health and Disease, pp. $345-$-361

[A. S. Prasad, editor]. New York: Academic Press.

Spring, J. A., Robertson, J. \& Buss, D. H. (1979). British Journal of Nutrition 41, 487-493.

Taylor Baer, M. \& King, J. C. (1984). American Journal of Clinical Nutrition 39, 556-570.

Thompson, J. N., Beare-Rogers, J. L., Erdödy, P. \& Smith, D. C. (1973). American Journal of Clinical Nutrition 26. $1349-1354$.

Thomson, A. M. (1958). British Journal of Nutrition 12, 446-461.

Whichelow, M. J. \& King, B. (1979). Archives of Diseases in Childhood 54, 240-241.

White, H. S. (1969). Journal of the American Dietetic Association 55, 38-43.

Whitehead, R. G. \& Paul, A. A. (1981). Lancet ii, 161-163.

Whitehead, R. G. \& Paul, A. A. (1982). In Nutrition and Health: A Perspective, pp. 159-168 [M. R. Turner, editor]. Lancaster: MTP Press.

Wiles, S. J., Nettleton, P. A., Black, A. E. \& Paul, A. A. (1980). Journal of Human Nutrition 34, $189-224$.

Witting, L. A. \& Lee, L. (1975). American Journal of Clinical Nutrition 28, 571-576.

Wolman, S. L., Anderson, G. H., Marliss, E. B. \& Jeejeebhoy, K. N. (1981). Gastroenterology 76, 458-467.

World Health Organization (1973). Trace Elements in Human Health. Technical Report Series no. 532. Geneva: WHO. 